\title{
An Evaluation Method for Hematological and Clinico- biochemical Values in Aged F 344 Rats on Chronic Toxicity Tests such as Long-term Inhalation Studies on the Effects of Diesel Exhaust
}

\author{
Kazuhito MAEJIMA and Sumi NAGASE* \\ Japan Automobile Research Institute, 2530 Karima, Tsukuba-shi, Ibaraki 305, \\ and* Sasaki Institute, 2-2 Surugadai, Kanda, Chiyoda-ku, Tokyo 101, Japan
}

(Received 12 September 1989/Accepted 27 December 1989)

\begin{abstract}
To determine the chronic toxicity of diesel exhaust, 2, 150 F 344 rats were made to inhale various dilutions of exhaust under specific pathogen-free conditions for 16 hours a day, 6 days a week, for 30 months. Ten experimental groups, each with 120 male and 95 female 5 week-old rats, were set up and 14 males and 9 females were usually sacrificed for measurement of the 51 hematological and clinico-biochemical parameters at $7,13,19$, and 25 months of age, respectively. These parameters were also examined in all surviving rats after 30 months of exhaust inhalation. In this experiment, no remarkable change in any of the parameters was observed in the periodic examinations. Therefore, tendencies of change in parameters were examined by comparing histograms for control and experimental groups. For the reference histograms, we used the values obtained from 144 males and 116 females aged 13-31 months. The first histogram was based on data from 1, 352 rats, and the range from the minimum to the maximum value was divided into eight parts. When almost all the values were centered on a peak in the first histogram, this peak was divided into a further eight parts in the second histogram. Histogram evaluation clarified the differences between the control and experimental groups better than general statistical methods such as Student's t-test.
\end{abstract}

\section{長期毒性試験（ディーゼル排ガス長期吸入試験） \\ に打ける高龄 F 344 ラットの血液学的・ \\ 臨床生化学的検査値の一評価法}

\author{
前島一化・長瀬すみ** \\ 財団法人日本自動車研究所第一研究部 \\ $*$ 財団法人佐々木研究所化学部
}

定期的な血液学的・臨床生化学的検査は，長期間の毒 性試験などでは不可欠な事項とされている [6]。著者ら は,ディーゼル排ガスの健康影響を調査する目的で, 慢性 毒性試験を中心とした30か月間の長期吸入実験を実施し $[1,4,9]$, その間 6 か月ごとにラットの血液学的・臨床生 化学的検査を行った。しかし，実験開始後 1 年を過きた 頃上り, 血液学的・臨床生化学的性状 (以後, 血液性状
と呼称）に異常値を示す個体が出現し始め, 吸入期間の 延長とともに平均値による実験群間の比較が難しくなる 項目が増加した。また，実験期間中に切迫検査されたラ ットは，血液データの得られたラットの約30\%に達し た。一方, 各定期検査では, ディーゼル排ガスによる血 夜性状への強い，あるいは特異的な影響があまりみられ なかった。そこで, 著者らは、ディーゼル排ガスの吸入 
による影響を血液データの得られた全てのラットを用い て全体的な傾向を把握することとした。

本研究では, これらの考えをもとに, 高龄 F 344 ラッ トの血液性状をヒストグラム（一定の範囲の測定値を示 した動物の出現頻度）で評価する方法について検討し た。

\section{材料と方法}

1. ディーゼル排ガスの長期吸入実験 : ディーゼル排ガ スの長期吸入実験は，以下の方法で実施した。直接噴射 式の大型ディーゼルェンジン（排気量 $11 \ell, \mathrm{HD}$ 系列） および渦流室式の小型ディーゼルェンジン（排気量 1.8 $\ell, \mathrm{LD}$ 系列）より発生させたディーゼル排ガス（以下， 排ガス）は, 各々の希釈トンネル内で清浄空気により希 釈し, 各吸入チャンバに導入した $[7]$ 。吸入チャンバに は, 内容積が3. $1 \mathrm{~m}^{3}$ で排ガスが水平方向に流れる横層流 方式のタイプを計10基用いた $[8]$ 。

各吸入チャンバ内には，標準的な飼育用ラック（集団 飼育用20ケージ/ラック，ケージサイズ : 400(H) $\times 280$ $(\mathrm{W}) \times 180(\mathrm{D}) \mathrm{mm}$, 最大 6 匹/ケージ) をそれぞれ 2 台ずつ収納し, 1 台に雄ラットを, 他の 1 台に雌ラット を収容した。

吸入チャンバの平均換気回数は, 排ガスの濃度分布を 均一に維持するために60回/時とし, この時の気流速度 はヶージ内で平均 $6 \mathrm{~cm} /$ 秒であった [8]。

ラットに対する排ガスの吸入は，1 日16時間（17:00 〜 :00）とし, 残りの8時間（ $9: 00 \sim 17: 00 ）$ は清 浄空気を吸入させ， 1 週間に 6 日吸入させた。なお，両 系列の対照群には, 清浄空気のみを吸入させた。

2. 実験群と排ガス濃度 : 実験群は, 各群の平均粒子濃
度を用いた呼称とした。Table 1 に実験群および各実 験群における主な排ガス成分の30か月間の平均濃度を示 す。

3. 供試動物と飼育管理：日本クレア（株）から4 週龄 で導入した2,150匹の雙雄 F 344/Jcl ラット (SPF) を， 1 週間の予備飼育後, 5 週齡より実験に用いた。各実験 群とも, 雄120匹, 雌95匹を使用し，そのらち発がん性 試験に雄64匹, 䊒59匹, 慢性毒性試験に雄56匹, 䊒36匹 を用いた。発がん性試験では，30か月間の吸入後（31か 月齢）に生存した全ラットを，また，慢性毒性試験で は，7，13，19および25か月㱓時に原則として各群雄 14 匹, 雌 9 匹を無作為に抽出して定期検査に供した。定期 検査の前に異常を観察したラットは，一定の判断基準 （体重変化, 負血度, 衰弱度などの程度）のもとに切迫 検査を行った。

飼料（日本クレア， CE-2）は， $121^{\circ} \mathrm{C} ， 30$ 分の高圧蒸 気隇菌したものを不断給䬣した。飲水は，逆浸透膜を通 した一般水に塩素を添加（残留塩素濃度が $0.1 \mathrm{ppm} に$ なるように調整）し，最終的に流水殺菌装置を通して自 動給水した。吸入チャンバを含む動物飼育区域では, 定期的に落下菌検査を実施した。照明は，7：00点灯， 19:00消灯の12時間サイクルとし, 各吸入チャンバ内の 温度は $23 \pm 2{ }^{\circ}$, 湿度は55士10\%に維持した [1]。

4. 試料の採取および測定方法：採血に供するラット は, 原則として24時間の絶食を行った。試験紙による屎 検査後、エーテルで麻酔したラットの腹部大動脈より, ヘパリン処理したシリンジで2. 5 3. $0 \mathrm{ml}$ 採血した（以 後, ヘパリン血と呼称)。続いて同部より採血針で採 血スピッツ（マイクロティナ, Becton Dickinson）に $0.3 \mathrm{ml}$ 採血し(以後, EDTA-2 K 血と呼称)，最後に 流出してくる全ての血夜を遠沈管に採取した。採血直後

Table 1. Summary of gases and particle concentrations (30 months)

\begin{tabular}{|c|c|c|c|c|c|}
\hline & Group & Particle $\left(\mathrm{mg} / \mathrm{m}^{3}\right)$ & NOx (ppm) & $\mathrm{NO}_{2}(\mathrm{ppm})$ & $\mathrm{SO}_{2}(\mathrm{ppm})$ \\
\hline & control & 0 & 0.05 & 0.02 & 0.06 \\
\hline \multirow{4}{*}{ LD } & $0.1 \mathrm{mg} / \mathrm{m}^{3}$ & 0.1 & 1.2 & 0.1 & 0.4 \\
\hline & $0.4 \mathrm{mg} / \mathrm{m}^{3}$ & 0.4 & 4.1 & 0.3 & 1.1 \\
\hline & $1.1 \mathrm{mg} / \mathrm{m}^{3}$ & 1.1 & 10.1 & 0.7 & 2.4 \\
\hline & $2.3 \mathrm{mg} / \mathrm{m}^{3}$ & 2.3 & 20.3 & 1.4 & 4.7 \\
\hline \multirow{4}{*}{$\mathrm{HD}$} & $0.5 \mathrm{mg} / \mathrm{m}^{3}$ & 0.5 & 6.2 & 0.5 & 1.0 \\
\hline & $1.0 \mathrm{mg} / \mathrm{m}^{3}$ & 1.0 & 13.1 & 1.0 & 1.8 \\
\hline & $1.8 \mathrm{mg} / \mathrm{m}^{3}$ & 1.8 & 21.7 & 1.7 & 2.8 \\
\hline & $3.7 \mathrm{mg} / \mathrm{m}^{3}$ & 3.7 & 37.5 & 3.0 & 4.6 \\
\hline
\end{tabular}

LD : Light duty diesel engine exhaust

HD : Heavy duty diesel engine exhaust 
のへパリン血は，その一部を血液 $\mathrm{pH}$ およびガスの測定 に用い, 残血は3,000 rpm, 10分間の冷却遠沈を 2 度綝 り返して血漿を分離した。また，遠沈管に採取した血夜 は, 室温に 1 時間放置後, 血漿と同様な方法で血清を分 離した [3]。EDTA-2 K 血は，血夜学的検査に用いた。 血液学的・臨床生化学的検査項目とその単位, 試料の 種類, 測定法および測定機器を Table 2-A，2-Bに示 す。なお，蛋白分画值は，セルロースアセテート膜によ る電気泳動法で測定した。膜には Titan III を, 緩衝液 にはイオン強度0.125のトリス・バルビタール・バルビ タールーナトリウム液を用いて電圧 $220 \mathrm{~V}$ ，泳動時間
45分の条件で泳動し，ポンソーSで染色した。染色した Titan IIIは、デンシトメータ（ヘレナ研究所）により各 蛋白分画値を算出した。

5.ヒストグラム：各群のヒストグラムは，血液データ の得られた全てのラット（定期検査 : 雄578匹，雌437匹， 切迫検査 : 雄164匹，雌173匹，計1,352匹 ; 全供試 ラッ トの約63\%）より，雌雄別に各項目ごとの最大值と最小 值を求め，その間を 8 クラスに等分割し，それぞれの值 の範用に相当するラットの分布を求める方法で作成し た。これを1次ヒストグラムとした。1次ヒストグラム において，分布がある1クラスに集中した場合は，その

Table 2- A. Parameters and methods for hematology and clinico-biochemistry

\begin{tabular}{|c|c|c|c|c|c|}
\hline Sample & Parameter & Abbreviation & Units & Method & Instrument \\
\hline & Clinico-biochemical analysis & & & & \\
\hline \multirow[t]{5}{*}{ Plasma } & Glutamic oxalacetic transaminase & GOT & $(\mathrm{IU} / \ell)$ & Karmen method & TBA-380 \\
\hline & Glutamic pyruvic transaminase & GPT & $(\mathrm{IU} / \ell)$ & " & \\
\hline & Lactate dehydrogenase & LDH & $(\mathrm{IU} / \ell)$ & Wröblewski LaDue meth & \\
\hline & $\alpha$-hydroxybutyrate dehydrogenase & HBD & $(\mathrm{IU} / \ell)$ & Rosalki method & \\
\hline & Creatine phosphokinase & $\mathrm{CPK}$ & $(\mathrm{IU} / \ell)$ & Oliver method & \\
\hline \multirow[t]{27}{*}{ Serum } & Alkaline phosphatase & ALP & $(\mathrm{IU} / \ell)$ & GSCC method & \\
\hline & Leucine aminopeptidase & LAP & $(\mathrm{IU} / \ell)$ & Nagel method & \\
\hline & Cholinesterase & $\mathrm{CHE}$ & $(\mathrm{IU} / \ell)$ & DTNB method & \\
\hline & Amylase & AMY & $(\mathrm{U} / d \ell)$ & Enzymatic method & \\
\hline & Blood urea nitrogen & BUN & $(\mathrm{mg} / \mathrm{d} \ell)$ & UV-Rate method & \\
\hline & Creatinine & CRTN & $(\mathrm{mg} / \mathrm{d \ell})$ & Jaffé method & \\
\hline & Total bilirubin & T-Bil & $(\mathrm{mg} / \mathrm{d \ell})$ & Jendrassik method & \\
\hline & Glucose & Glu & $(\mathrm{mg} / \mathrm{d \ell})$ & Enzymatic method & \\
\hline & Triglyceride & TRG & $(\mathrm{mg} / \mathrm{d \ell})$ & GPO method & \\
\hline & Total cholesterol & $\mathrm{T}-\mathrm{CHO}$ & $(\mathrm{mg} / \mathrm{d \ell})$ & Enzymatic method & \\
\hline & Free cholesterol & $\mathrm{F}-\mathrm{CHO}$ & $(\mathrm{mg} / \mathrm{d \ell})$ & $"$ & \\
\hline & Low density lipoprotein & LDL & $(\mathrm{mg} / \mathrm{d \ell})$ & Heparin-Ca method & \\
\hline & High density lipoprotein & HDL & $(\mathrm{mg} / \mathrm{d \ell})$ & Enzymatic method & \\
\hline & Pospholipid & $\mathrm{P}-\mathrm{L}$ & $(\mathrm{mg} / \mathrm{d \ell})$ & $\prime$ & \\
\hline & Calcium & $\mathrm{Ca}$ & $(\mathrm{mg} / \mathrm{d \ell})$ & OCPC method & \\
\hline & Magnesium & $\mathrm{Mg}$ & $(\mathrm{mg} / \mathrm{d \ell})$ & Xylidyl blue method & \\
\hline & Inorganic phosphorus & IP & $(\mathrm{mg} / \mathrm{d} \ell)$ & Molybdenum blue method & \\
\hline & Sodium & $\mathrm{Na}$ & $(\mathrm{mEq} / \ell)$ & Electrode method & $\mathrm{Na}-\mathrm{K}$ analyzer \\
\hline & Potassium & $\mathrm{K}$ & $(\mathrm{mEq} / \ell)$ & " & " \\
\hline & Chloride & $\mathrm{CI}$ & $(\mathrm{mEq} / \ell)$ & $"$ & Chloride meter \\
\hline & Total protein & $\mathrm{TP}$ & $(\mathrm{g} / d \ell)$ & Refract method & Refractmeter \\
\hline & Albumin & AIb & $(\%)$ & Cellulose acetate & Auto scanner \\
\hline & $\alpha_{1}$-globulin & $\alpha_{1}-G$ & $(\%)$ & electrophoresis & flur vis and \\
\hline & $\alpha_{2^{-}} \quad \prime$ & $\alpha_{2}-\mathrm{G}$ & $(\%)$ & & quick quant III \\
\hline & $\alpha_{3^{-}} \quad \prime$ & $\alpha_{3}-G$ & $(\%)$ & & \\
\hline & $\beta-\quad \prime$ & $\beta-G$ & $(\%)$ & & \\
\hline & $\gamma-" \prime$ & $\gamma-G$ & $(\%)$ & & \\
\hline
\end{tabular}


Table 2- B. Parameters and methods for hematology and clinico-biochemistry

\begin{tabular}{|c|c|c|c|c|c|}
\hline Sample & Parameter & Abbreviation & Units & Method & Instrument \\
\hline \multirow{10}{*}{$\begin{array}{l}\text { Blood } \\
\text { with } \\
\text { EDTA-2K }\end{array}$} & Hematological analysis & & & & \\
\hline & Erythrocyte count & $\mathrm{RBC}$ & $\left(\times 10^{6} / \mu \ell\right)$ & Laser-ray method & ELT-8 \\
\hline & Leucocyte count & WBC & $\left(\times 10^{3} / \mu \ell\right)$ & " & \\
\hline & Platelet count & PLT & $\left(\times 10^{3} / \mu \ell\right)$ & $"$ & \\
\hline & Hematocrit & HCT & $(\%)$ & $"$ & \\
\hline & Hemoglobin concentration & $\mathrm{HGB}$ & $(\mathrm{g} / d \ell)$ & Cyanmethemoglobin & \\
\hline & & & & modified method & \\
\hline & Mean corpuscular volume & $\mathrm{MCV}$ & $(\mathrm{f} \ell)$ & Calculation & \\
\hline & Mean corpuscular hemoglobin & $\mathrm{MCH}$ & (pg) & . " " & \\
\hline & $\begin{array}{l}\text { Mean corpuscular hemoglobin } \\
\text { concentration }\end{array}$ & $\mathrm{MCHC}$ & $(\%)$ & $\|$ & \\
\hline \multirow{6}{*}{$\begin{array}{l}\text { Blood } \\
\text { with } \\
\text { heparin } \\
\text { sodium }\end{array}$} & Blood $p H$ and gas analysis & & & & \\
\hline & Blood pH & $\mathrm{pHa}$ & & Electrode method & Corning 158 \\
\hline & Carbon dioxide partial pressure & $\mathrm{PaCO}_{2}$ & $(\mathrm{mmHg})$ & " & \\
\hline & Oxygen partial pressure & $\mathrm{PaO}_{2}$ & (mmHg) & $"$ & \\
\hline & Bicarbonate & $\mathrm{HCO}_{3}-$ & $(\mathrm{mmo} \ell / \ell)$ & Calculation & \\
\hline & Oxygen saturation & $\mathrm{O}_{2} \mathrm{SAT}$ & $(\%)$ & $"$ & \\
\hline \multirow{7}{*}{ Urine } & Urinalysis & & & Dipsticks & Uropaper \\
\hline & Urinary $\mathrm{pH}$ & & & & \\
\hline & Protein & & & & \\
\hline & Urobilinogen & & & & \\
\hline & Glucose & & & & \\
\hline & Occult blood & & & & \\
\hline & Body weight at exsanguination & $\mathrm{BW}$ & (g) & & \\
\hline
\end{tabular}

中をさらに 8 クラスに等分割し，2次ヒストグラムを作 成した。なお，LD, HD 両系列の吸入実験は同時に行 われささらに両系列の対照群とも吸入チャンバの形状や 飼育環境条件などには差を認めなかった [1]ことから， 本研究での対照群の血液学的・臨床生化学的測定值は, 両系列の対照群の值を合わせたものを用いた。

6. 評価法の比較 : 毒性試験などで、対照群と実験群と の間の評価によく用いられる Student's t-test (以後, 平均值法と呼称）と本研究でのヒストグラムによる方法 (以後, ヒストグラム法と呼称) とをいくつかの項目に ついて比較した。なお，ヒストグラムでは，最小值側 （左側）をクラス 1 とし, 最大值側（右側）をクラス 8 とした。

\section{成 縤}

\section{1. 検査ラットの月齡分布拉よび死亡率の推移}

1.1 検查ラットの月龄分布

対照群に㧊ける各項目の加龄に伴ら概括的な変動パタ
ーン(13か月齢時の平均値を 1 とした時の経時変化) と， 各変動パターンに相当する項目を Fig. 1 亿示す。変動 パターンは，13か月龄から31か月龄にかけて以下の6つ のパターンに分類された。

(1) : 加齢に伴って大きく上昇し，31か月齢時には13か

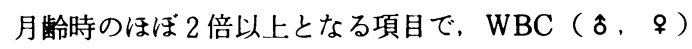
などにみられた。(2)：加龄に伴って若干上昇する傾向を 示す項目で, PLT（す，\&）などにみられた。(3)：加 龄に伴って若干上昇するが, 後半には逆に低下する傾向 を示す項目で, Glu（১，\&）にみられた。(4)：(3)と逆 のパターンで, 加龄に伴って若干低下寸るが, 後半には 上昇する傾向を示す項目で，GOT（す，\&）などにみ られた。(5)：加龄に伴って若干低下する傾向を示す項目 で、 RBC（o，\&）などにみられた。(6)のハターンは, 加齢に伴ら大きな変動を示さない項目で $\mathrm{pHa}(\hat{o} ， \& ）$ などにみられた。

加龄に伴う変動を示す(1)〜5の項目では，各群間で採 血時の月龄分布に極端なアンバランスが生じた場合, ヒ ストグラムによる解析を誤る可能性がある。そこで, 検 


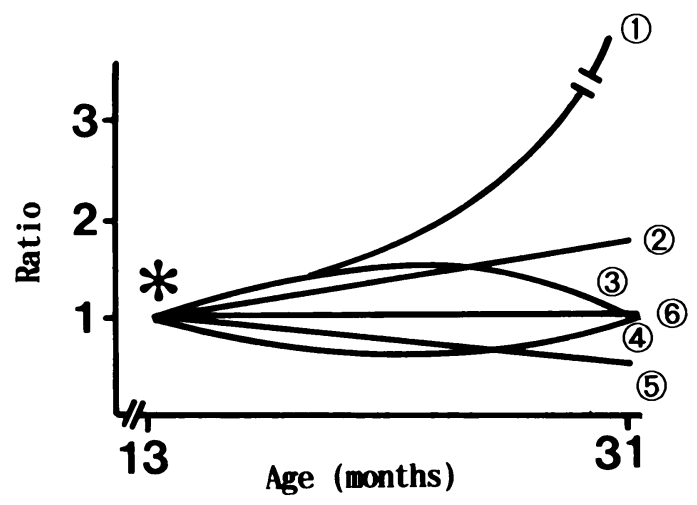

* Values of 13 month-old : 1

Pattern

Parameter

(1) $\operatorname{WBC}\left(\sigma^{7}\right.$, ㅇ $), \operatorname{T}-\mathrm{CHO}\left(\sigma^{7}\right), \mathrm{F}-\mathrm{CHO}\left(\sigma^{7}\right), \operatorname{TRG}\left(\sigma^{7}\right.$, 우 $), \operatorname{LDL}\left(\sigma^{7}\right.$, 우 ),

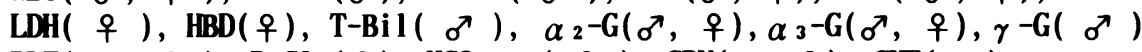

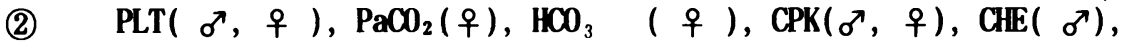
AMY ( 우), BUN( $\left.\sigma^{\gamma}\right), \mathrm{T}-\mathrm{Bil}\left(\right.$ 우), T-CHO( 우), $\mathrm{F}-\mathrm{CHO}\left(\right.$ 우 ), $\mathrm{P}-\mathrm{L}\left(\sigma^{7}\right.$, 우), $\mathrm{HDL}\left(\sigma^{\gamma}\right.$, 우 $), \alpha_{1}-\mathrm{G}\left(\sigma^{7}\right.$, 우), $\gamma-\mathrm{G}($ 우 $), \mathrm{BW}$ ( 우)

(3) $\mathrm{Glu}\left(\sigma^{7}\right.$, 우)

(4) $\operatorname{GOT}\left(\sigma^{\gamma}\right.$, 우 ), $\operatorname{GPT}\left(\sigma^{7}\right), \operatorname{LDH}\left(\sigma^{\gamma}\right), \operatorname{HBD}\left(\sigma^{7}\right), \operatorname{ALP}\left(\sigma^{7}\right.$, 우 ),

(5) $\operatorname{ALB}\left(\sigma^{7}\right.$, 우 $), \operatorname{RBC}\left(\sigma^{7}\right.$, 우 $), \operatorname{HGB}\left(\sigma^{\gamma}\right.$, 우), $\operatorname{HCT}\left(\sigma^{7}\right.$, 우 $), \operatorname{LAP}\left(\sigma^{7}\right.$, 우 $)$, $\mathrm{CHE}$ ( क \& ), BW( o⿱)

(6) $\operatorname{MCV}\left(\sigma^{7}\right.$, ㅇ $), \operatorname{MCH}\left(\sigma^{7}\right.$, 우), $\operatorname{MCHC}\left(\sigma^{7}\right.$, 우), $\mathrm{pHa}\left(\sigma^{7}\right.$, 우 $), \mathrm{PaCO}_{2}\left(\sigma^{7}\right)$, $\mathrm{PaO}_{2}\left(\sigma^{\circ}\right.$, 우 $), \mathrm{HCO}_{3}\left(\sigma^{\gamma}\right), \mathbf{0}_{2} \operatorname{SAT}\left(\sigma^{7}\right.$, 우), $\operatorname{AMY}\left(\sigma^{7}\right), \operatorname{CRTN}\left(\sigma^{\circ}\right.$, 우 ), CPT( 우), $\mathrm{BUN}\left(\right.$ 우 ) $\mathrm{Ca}\left(\sigma^{\circ}\right.$, 우), $\mathrm{Mg}\left(\sigma^{7}\right.$, 우), $\mathrm{IP}\left(\sigma^{\circ}\right.$, 우), $\mathrm{Na}\left(\sigma^{7}\right.$, ㅇ $)$, $\mathrm{K}\left(\sigma^{\gamma}\right.$, 우 $), \mathrm{Cl}\left(\sigma^{7}\right.$, 우), $\mathrm{TP}\left(\sigma^{7}\right.$, 우), $\beta-\mathrm{G}\left(\sigma^{\gamma}\right.$, 우),

Fig. 1. Pattern of aged-related changes in hematological and clinicotiochemical values in $\mathrm{F} 344$ rats aged from 13 to 31 months

査ラットの月龄分布について検討を加えた。

対照群の雄 (雌) の定期検査数と切迫検査数の全検 査数に対する比率は，それぞれ13〜17か月龄で19.4\% と $1.4 \%(14.7 \%, 2.6 \%), 18$ 22か月齢で19.4\%と6.9\% (15.5\%，9.5\%)，23〜27か月龄で13.9\%と6.9\%（8.6 $\%, 8.6 \%) ， 28 \sim 31$ か月龄で20.1\%と $11.8 \%$ (31.0\%, 9.5\%), 全体では72.9\%と27.1\%（69.8\%, 30.2\%）で あった。

これに対し, 最高濃度群の $3.7 \mathrm{mg} / \mathrm{m}^{3}$ 群では, 同様 に13〜17か月龄；18.1\%，1.4\%（13.5\%，1.9\%)，18 ２22か月龄；19.4\%，6.9\%（9.6\%，1.9\%)，23〜27か

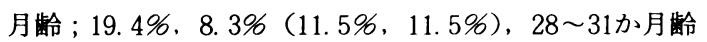
; $20.8 \%, 5.6 \%(42.3 \%, 7.7 \%)$, 全体では77.8\%, $22.2 \%(76.9 \%, 23.1 \%)$ であり, $3.7 \mathrm{mg} / \mathrm{m}^{3}$ 群と同
様他の実験群においても対照群との間に著しい差異は認 められなかった。

\section{2 死亡率の推移}

発がん性試験に用いたラット（HD 系列）の群別死亡 率の推移を Fig. 2 (雄) と Fig. 3 (雌) に示す。対 照群の䊒雄は，いずれも19か月齢で約 $5 \%$ ，25か月齢で 䄪20\%の死亡率を示した。その後, 雌雄とも死亡率の急 激な上昇がみられ，31か月龄では約70\%の死亡率であっ た。これに対し，実験初期の $3.7 \mathrm{mg} / \mathrm{m}^{3}$ 群の雌では，

7 か月齢頃より死亡するラットが数例みられ, 他の実験 群よりやや低く推移した。しかし，16か月龄頃より死亡 するラットの数は他の群との間に差がみられなくなり, 31 か月齢では死亡率63\%で対照群との間に差はみられな かった。その他の実験群(LD 系列を含む)では, 死亡率 


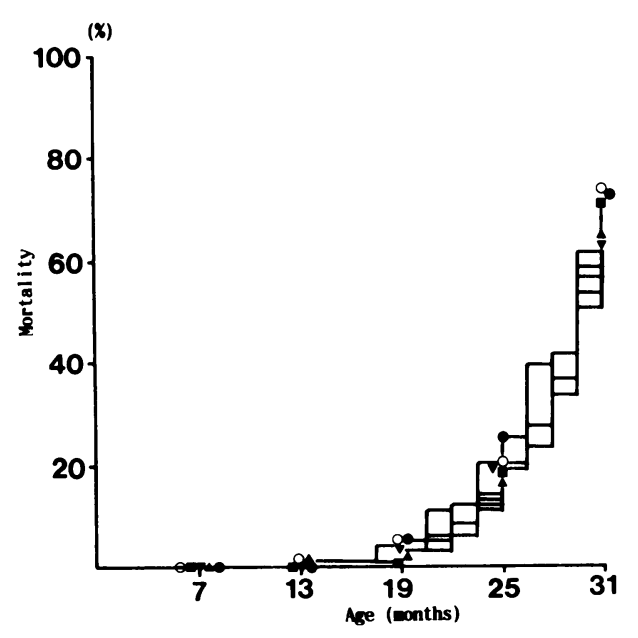

Fig. 2. Cumulative mortality curves of male F 344 rats exposed to heavy duty diesel engine exhaust for 30 months $\bigcirc$ : control group (fresh air) $: 0.5 \mathrm{mg} / \mathrm{m}^{3}$ group (particle : $\left.0.5 \mathrm{mg} / \mathrm{m}^{3}, \quad \mathrm{NO}_{2}: 0.5 \mathrm{ppm}, \mathrm{SO}_{2}: 1.0 \mathrm{ppm}\right)$ $\boldsymbol{\nabla}: 1.0 \mathrm{mg} / \mathrm{m}^{3}$ group (particle : $1.0 \mathrm{mg} / \mathrm{m}^{3}$, $\left.\mathrm{NO}_{2}: 1.0 \mathrm{ppm}, \mathrm{SO}_{2}: 1.8 \mathrm{ppm}\right) \Delta: 1.8 \mathrm{mg} / \mathrm{m}^{3}$ group (particle : $1.8 \mathrm{mg} / \mathrm{m}^{3}, \mathrm{NO}_{2}: 1.7 \mathrm{ppm}$, $\mathrm{SO}_{2}: 2.8 \mathrm{ppm}$ ) $: 3.7 \mathrm{mg} / \mathrm{m}^{3}$ group (particle : $\left.3.7 \mathrm{mg} / \mathrm{m}^{3}, \mathrm{NO}_{2}: 3.0 \mathrm{ppm}, \mathrm{SO}_{2}: 4.6 \mathrm{ppm}\right)$

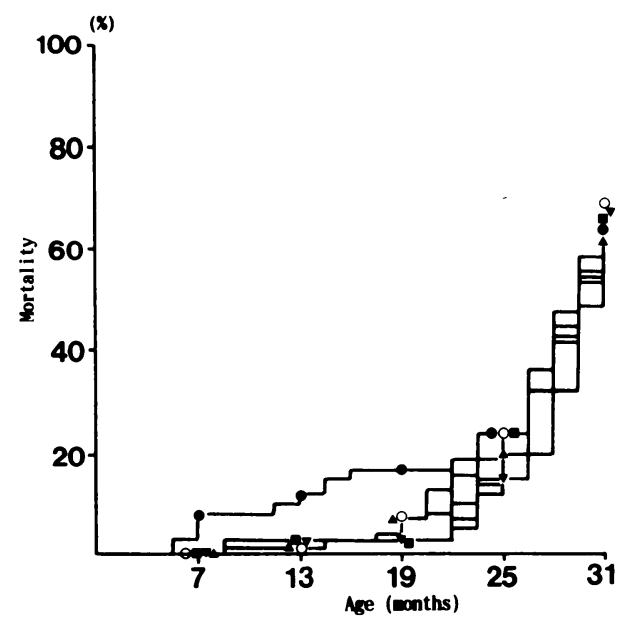

Fig. 3. Cumulative mortality curves of female F 344 rats exposed to heavy duty diesel engine exhaust for 30 months. Marks and experimental groups are the same as those for Fig. 1.
の推移に対照群との差異はみられなかった。実験初期に みられた $3.7 \mathrm{mg} / \mathrm{m}^{3}$ 群（雌）の数匹の死亡例は, 死亡 直前に急激な体重減少を示した以外, 病理組織学的にも 特別な異常所見は認めなかった。

実験期間中, Sendai virus と Mycoplasma pulmonis は全供試ラットの $31 \%$, Tyzzer's organismは18 $\%$. Corynebacterium kutscheri, Salmonella typhimuriym, Mouse hepatitis virus および Mouse adenovirusは11\%について血清反応による微生物学的 検査を実施したが，全例とも陰性であった。また，吸入 チャンバを含む動物飼育区域での平均落下菌数は，1時 間あたり 3 個/ 1 シャーレ以下であり，微生物学的に良 好な環境であった [2]。

2. 評価法の比較

2.1 平均值法とヒストグラム法が比較的対応した 変化を示している例

3. $7 \mathrm{mg} / \mathrm{m}^{3}$ 群と対照群(雄)のケーグロブリンの推移を Fig. 4 に示す。31か月龄における定期検査では, 3.7 $\mathrm{mg} / \mathrm{m}^{3}$ 群が対照群よりやや低い值を示したが, 13, 19 および25か月龄時の定期検査ではいずれも $3.7 \mathrm{mg} / \mathrm{m}^{3}$ 群 が対照群より高く，しかも13および25か月龄時では統計 学的にも有意な差が認められた。一方, この両群の $r$ グロブリンのヒストグラムを Fig. 5に比較した。対照 群は, クラス 1 にメインピークを持つ分布を示したのに

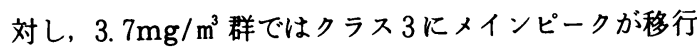
し, 平均値法と同様に対照群に対する明らかな増加傾向 が認められた。

本実験では、このアーグロブリンのように両評価法で ほぼ同様な傾向を示した項目が比較的多く認められた。

2.2 平均値法では明確な変化を把握できない例

(1) $1.0 \mathrm{mg} / \mathrm{m}^{3}$ 群, $3.7 \mathrm{mg} / \mathrm{m}^{3}$ 群および対照群 (倠) の血清総蛋白質の推移を Fig. 6 亿示す。13 か月龄時に おいて $3.7 \mathrm{mg} / \mathrm{m}^{3}$ 群が対照群に比べ有意な减少を示し た以外特に著しい変化は見られないと一般的には判 断するケースであろう。しかし，この3群の血清総蛋白 質のヒストグラムを Fig. 7. に比較すると, 対照群と $1.0 \mathrm{mg} / \mathrm{m}^{3}$ 群はクラス 6 にメインピークを持つほぼ同 じ分布を示したのに対し, $3.7 \mathrm{mg} / \mathrm{m}^{3}$ 群ではメインピー クがクラス 5 に移行し. $3.7 \mathrm{mg} / \mathrm{m}^{3}$ 群の血清総蛋白質 は, 対照群に比べ明らかに減少していることが認められ た。

（2） $0.1 \mathrm{mg} / \mathrm{m}^{3}$ 群, $2.3 \mathrm{mg} / \mathrm{m}^{3}$ 群および対照群（倠） のクレアチンホスフォキナーセ活性の推移を Fig. 8 に 示す。 25 か月龄時の $2.3 \mathrm{mg} / \mathrm{m}^{3}$ 群で有意な上昇がみら れた以外顕著な変化が認められない項目であり, しか 
(\%)

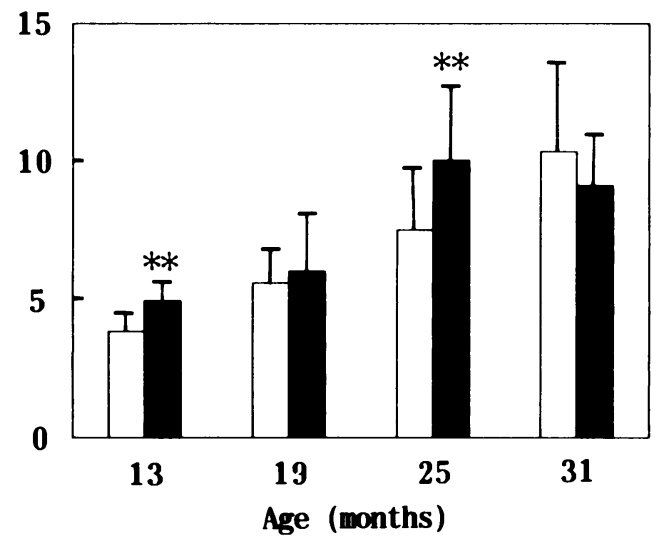

Fig. 4. Changes in serum $\gamma$-globulin concentration in 13-to 31-month-old F 344 male rats in the control and $3.7 \mathrm{mg} / \mathrm{m}^{3}$ groups. Columns and bars represent means \pm S. D. ${ }^{* *}: p<0.01$ ; significantly different from the control. $\square$ : control, $\mathbf{\square}: 3.7 \mathrm{mg} / \mathrm{m}^{3}$

(x)

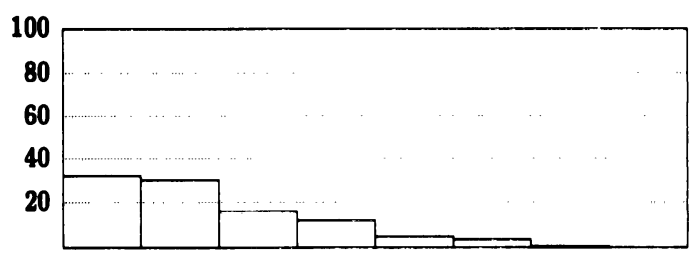

(x)

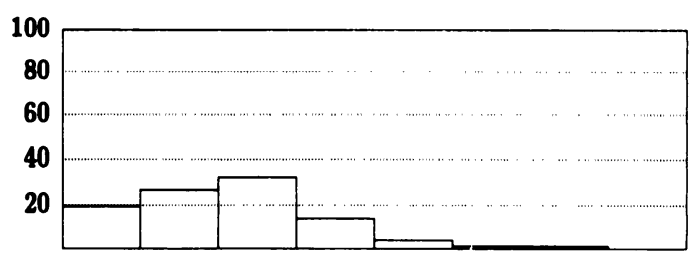

$\begin{array}{lllllllll}2.3 & 5.0 & 7.7 & 10.4 & 13.1 & 15.8 & 18.5 & 21.2 & \text { (x) }\end{array}$

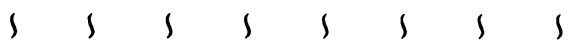

\section{$\begin{array}{llllllll}4.9 & 7.6 & 10.3 & 13.0 & 15.7 & 18.4 & 21.1 & 23.8\end{array}$}

Fig. 5. Distributions of serum $\gamma$-globulin concentration in 13-to 31-month-old F 344 male rats in the control (upper, $\mathrm{n}: 142$ ) and $3.7 \mathrm{mg}$ $/ \mathrm{m}^{3}$ (bottom, $\mathrm{n}: 71$ ) groups

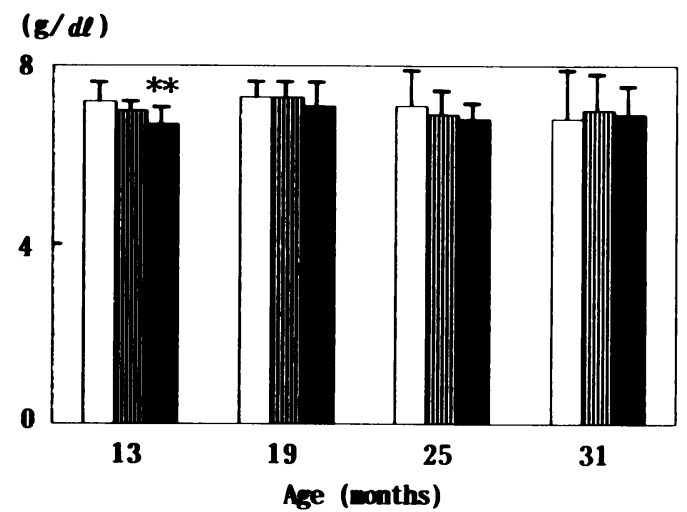

Fig. 6. Changes in serum total protein concentration in 13-to 31-month-old $\mathrm{F} 344$ female rats in the control, $1.0 \mathrm{mg} / \mathrm{m}^{3}$, and $3.7 \mathrm{mg} / \mathrm{m}^{3}$ groups. Columns and bars represent means \pm S. D. ${ }^{* *}: p<0.01$; significantly different from the control $\square:$ control $\mathbb{m}: 1.0 \mathrm{mg} / \mathrm{m}^{3}$ 口: $3.7 \mathrm{mg} / \mathrm{m}^{3}$

(x)

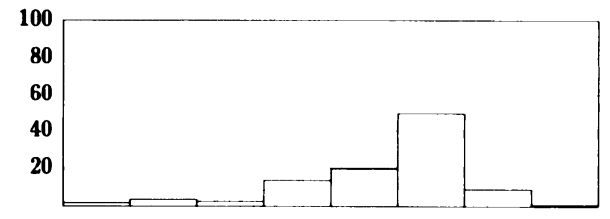

(\%)

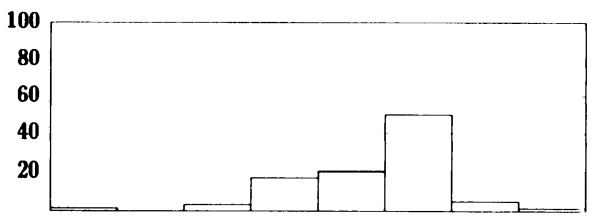

(\%)

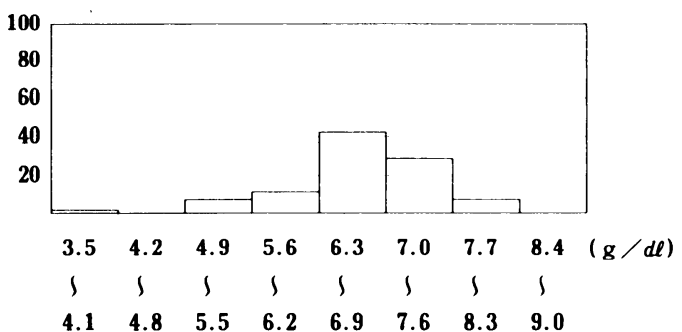

Fig. 7. Distributions of serum total Protein concentration in 13-to 31-month-old F344 female rats in the control (upper, $\mathrm{n}: 113), 1.0$ $\mathrm{mg} / \mathrm{m}^{3}$ (middle, $\mathrm{n}: 58$ ), and $3.7 \mathrm{mg} / \mathrm{m}^{3}$ (bottom, $\mathrm{n}: 52)$ groups 


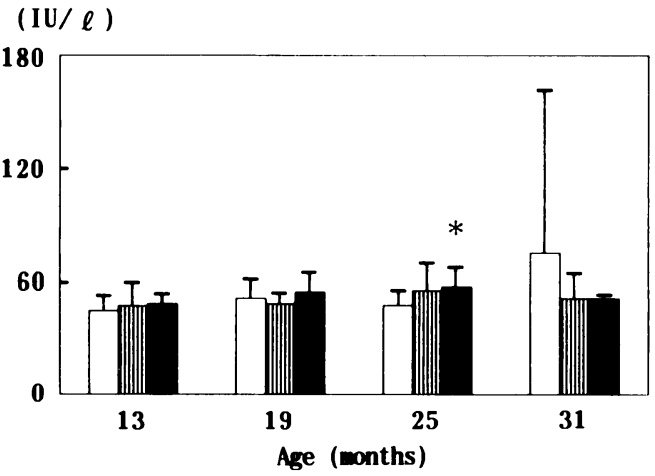

Fig. 8. Changes in plasma creatine phosphokinase activity in 13-to 31-month-old F 344 female rats in the control, $0.1 \mathrm{mg} / \mathrm{m}^{3}$, and 2.3 $\mathrm{mg} / \mathrm{m}^{3}$ groups. Columns and bars represent means \pm S. D. ${ }^{*}: p<0.05$; significantly different from the control $\square:$ control $\mathbb{m}: 0.1$ $\mathrm{mg} / \mathrm{m}^{3} \quad: 2.3 \mathrm{mg} / \mathrm{m}^{3}$

(x)

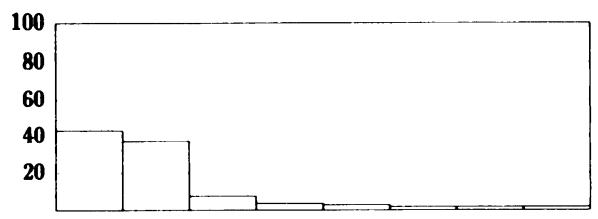

(x)

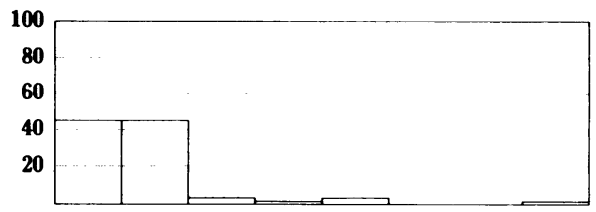

(\%)

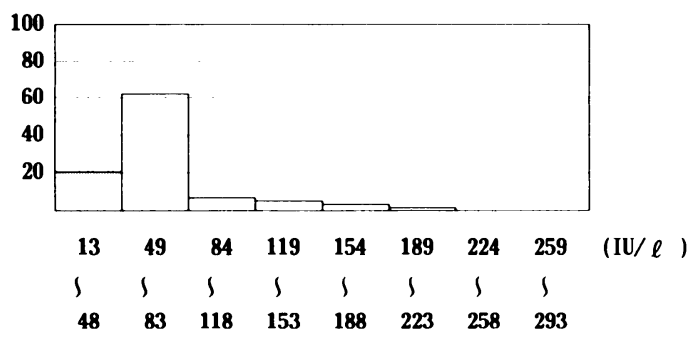

Fig. 9. Distributions of plasma creatine phosphokinase activity in 13-to 31-month-old F 344 female rats in the control (upper, $\mathrm{n}: 113$ ), 1.0 $\mathrm{mg} / \mathrm{m}^{3}$ (middle, $\mathrm{n}: 61$ ), and $3.7 \mathrm{mg} / \mathrm{m}^{3}$ (bottom, $\mathrm{n}: 66)$ groups
$(\mathrm{IU} / \ell)$

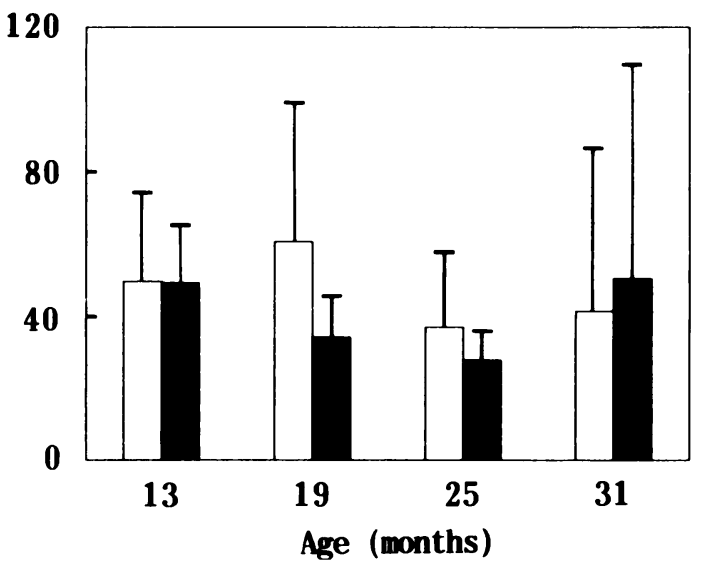

Fig. 10. Changes in plasma glutamic pyruvic transaminase activity in 13-to 31 -month-old F 344 female rats in the control and $0.4 \mathrm{mg} / \mathrm{m}^{3}$ groups. Columns and bars represent means \pm S. D. $\square:$ control $\square: 0.4 \mathrm{mg} / \mathrm{m}^{3}$
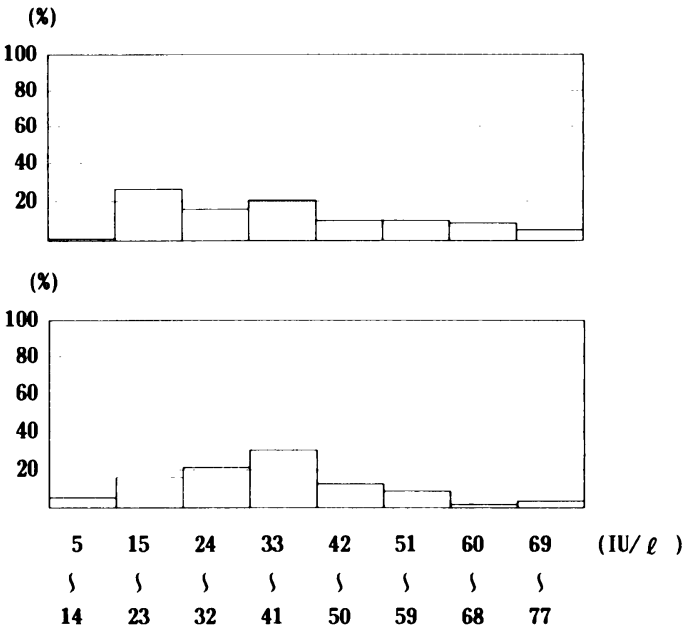

Fig. 11. Distributions of plasma glutamic pyruvicttransaminase activity in 13-to 31 -monthold F344 female rats in the control (upper, $\mathrm{n}: 87$ ), and $0.4 \mathrm{mg} / \mathrm{m}^{3}$ (bottom, $\mathrm{n}: 56$ ) groups 
も，1次ヒストグラムでも差がみられなかった。しか し，Fig. 9に示す2次ヒストグラムで比較すると，0.1 $\mathrm{mg} / \mathrm{m}^{3}$ 群では対照群との間に差が見られないものの， 2. $3 \mathrm{mg} / \mathrm{m}^{3}$ 群ではメインピークがクラス 2 に移行し, 対 照群に対する上昇傾向が認められた。

(3) $0.4 \mathrm{mg} / \mathrm{m}^{3}$ 群と対照群 (倠) の GPT 活性の推 移を Fig. 10 亿示す。各定期検査時において $0.4 \mathrm{mg} / \mathrm{m}^{3}$ 群と対照群の間には統計学的に有意な差を認めず，ま た，全体的な傾向む把握できない項目である。しかし， Fig. 11に示す2次ヒストグラムで比較すると, 対照群 がクラス 2 にインピークを持つ分布を示していたのに 対し, $0.4 \mathrm{mg} / \mathrm{m}^{3}$ 群では, メインピークがクラス 4 に移 行して扣り，対照群に対する若干の上昇傾向を認め た。

\section{考察}

長期間にわたる毒性試験での血液学的・臨床生化学的 な評価では，特に実験後期における評価が問題となる場 合が多い［5］。その大きな原因として，動物の加龄に伴 5個体差（測定值のバラッキ）の桩大をあげることがで きる。自然発生腫瘍 [10］は，その個体差を払大させる 重要な要因の一つであろら。全ての血液学的・臨床生化 学的測定項目が個体差の少ない推移を示す場合には, 統 計学的な検定も信頼の高いものになる。しかしながら, 動物の加龄に伴って個体差が払大した場合には, 平均値 だけで群間の差を評価することは, 被験物質の生体への 影響に対する判断を䛊らせる可能性むある。また，統計 学的手段としてょく使用される棄却検定も，高齢ラット への適用は考えさせられる。長期の慢性毒性試験などで は, 老化の影響と被験物質の影響が絡み合って解釈の困 難な場面に直面することも少なくなく, 安易な統計処理 を行うことは慎重であるべきである。

一方, 各定期検査の間に切迫検査した動物の評価の問 題もあげられる。特に 2 年以上の実験において切迫検査 された動物の比率が大きくなった場合には，定期検査動 物と切迫検查動物を合わせて評価する方法も同時に検討 する必要があろう。

著者らはこれらの条件を満たす方法として，SPF 環 境下で 1 年 2 年半飼育した高齢 F 344 ラットから得ら れた血夜性状に関するデータをヒストグラムの形で整理 し, このヒストグラムのパターンの変化で比較する方法 を検討した。

その結果, 本実験では Fig. 4, 5に示した ブリンのように，平均値による評価とヒストグラムによ
る評価とが注湆同じ傾向を示すものが比較的多くみられ たが，Fig. 10に示したGPT 活性のように，平均値によ る比較では傾向すらも把握できない項目もすくなからず みられた。しかも，この GPT 活性は，1次ヒストグラ ムではその傾向が把握できず，2次ヒストグラムにおい て，すなわち大部分のラットが示寸值の範囲での比較に おいてのみその差が確認できた。

定期検査で得られる各測定項目の平均値による評価法 は, 統計学的処理を行いやすいことと，増加（上昇）あ るいは減少（低下）などの変化の推移を把握するにはよ い方法である [11]。しかし，途中で切迫検査に供された 動物や統計学的有意差が認められないような場合の評価 には，難点があると考えられる。

一方，ヒストグラムによる評価法では，対照群と実験 群の死亡率に顕著な差が無いこと，また，検査動物数が ある程度必要であるなどの条件を要する。しかしなが ら，本吸入実験の上うに被験物質の直接的な影響によ る，強いあるいは特異的な変化があまり見られないよう な場合には，定期検査と切迫検査の動物を合わせて検討 し，被験物質の影響を全体的に把握する方法も有効な評 価法の一つであると考えられる。

\section{要 約}

ディーゼル排ガスの吸入による慢性毒性を調べる目的 で，2，150匹のF 344 ラットに希釈ディーゼル排ガスを 1 日16時間，週 6 日の条件で最長30か月間吸入させた。実 験群は，雄120匹几，雌95匹ずつ計10群を設定し，各群よ

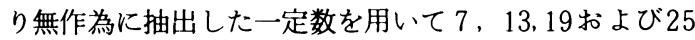
か月齢時に, 51 の血液学的・臨床生化学的項目を測定し た。また，30か月間の吸入実験が終了した時点で，生存 していた全てのラットに対し同様の測定を行った。本実 験の後期（13か月齢以降）に打ける対照群と実験群との 血夜学的・臨床生化学的な差異をより明らかにする目的 でヒストグラムによる評価を行った。その結果，ヒスト グラムによる評価法は, 通常用いられる平均值による評 価法に比べ対照群と実験群との間の差をより明確にする ことができた。

\section{文 献}

[1] Ishinishi, N., Kuwabara, N., Nagase, S., Suzuki, T., Ishiwata, S., and Kohno, T. (1986). Long-term inhalation studies on effects of exhaust from heavy and light duty engines on F 344 rats. In Carcinogenic and Mutagenic Effects of Diesel Engine Exhaust, pp 329-348, Ishinishi, N, Koizumi, A., McClellan, R. O., and Stöber, W. (edits.), Elsever, Amsterdam. 
[2] Maejima, K., Koizumi, S., and Takahashi, H. (1987). Observation on airborne bacteria in JARI labolatory animal facility. J. Japan Automa. Res. Inst., 9, 216219.

[3] Maejima, K., Tamura, K., Murano, M., Nakajima, T., Sueyoshi, Y., Suzuki, T., and Nagase, S. (1987). The effects of diesel exhaust on certain hematological, chemico-clinical parameters and tissue LDH activities in rats. $J$ Japan Automa. Res. Inst., 9, 54-57.

[4] Maejima, K. and Nagase, S. (1989). Hematological and clinico-biochemical studies on F 344 rats inhaled diesel engine exhaust. Proceedings of the 8 th World Air Congress 1989. The Netherlands, 2, pp. 149-154. Elsever, Amsterdam.

［5] 長瀬すみ・田中寿子 (1976). 実験動物の臨床生化学デ 一タ，ソフトサイェンス, 東京.

[6] 大森義仁(1981). OECD 化学物質毒性試呀指針, 化学工 業日報社, 東京.

[7] Suzuki, T., Nakajima, T., Sueyoshi, Y., and Ito, T. (1985). Aimal exposure facility for diesel engine exhaust emission $J$ Japan Automa Res. Inst., 7 , 238-241.

[8] Suzuki, T., Nakajima, T., Sueyoshi, Y., and Ito, T. (1985). Design and characteristics of inhalation chamber for animal experiment. J. Japan Automa Res. Inst., 7, 281-284.

[9] Suzuki, T., Nakajima, T., Maejima, K., and Kato, A. (1989). Long-term inhalation studies on the effects of diesel emissions on experimental animals. 18 th international congress on combustion engines, CIMAC TIANJIN' 89 , FISITA SESSION. pp. 29-34, Society of Automotive Engineers of Japan, Inc.

[10] Takaki, Y., Kitamura, S., Uekusa, T., Honma, S., Aze, Y., Wakabayashi, K., Kuwabara, N., and Fukuda, Y. (1989). Spontaneous tumors in $\mathrm{F}-344 / \mathrm{Jcl}$ rats. $J$. Toxicol Sci, 14, 181-195.

[11] Tamura, K., Maejima, K., and Nagase, S. (1989). Hematological and clinico-biochemical effects of short-term inhalation of $\mathrm{O}_{3}, \mathrm{NO}_{2}$, and $\mathrm{SO}_{2}$ on rats. J. Japan Aut oma Res Inst., 11, 326-329. 